\title{
CORRIGENDUM
}

Genes \& Development 32: 1499-1513 (2018)

\section{Corrigendum: Adaptation to DNA damage checkpoint in senescent telomerase- negative cells promotes genome instability}

Héloïse Coutelier, Zhou Xu, Mony Chenda Morisse, Maoussi Lhuillier-Akakpo, Serge Pelet, Gilles Charvin, Karine Dubrana, and Maria Teresa Teixeira

In the above-mentioned article, the Supplemental movie files were inadvertently excluded. These files have now been added to the Supplemental Material online.

doi:10.1101/gad.324459.119 


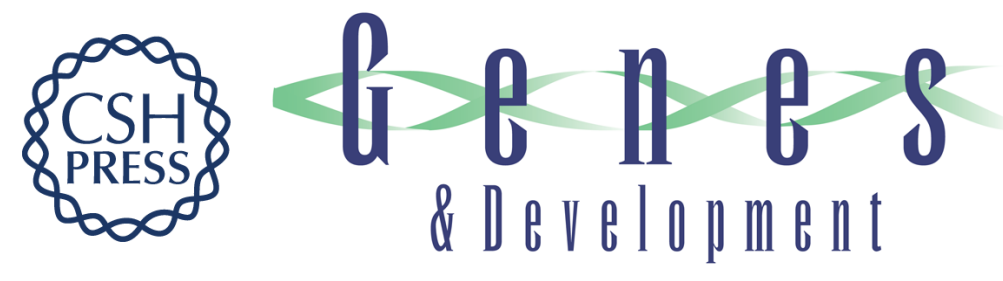

\section{Corrigendum: Adaptation to DNA damage checkpoint in senescent telomerase-negative cells promotes genome instability}

Hélö̈se Coutelier, Zhou Xu, Mony Chenda Morisse, et al.

Genes Dev. 2019, 33:

Access the most recent version at doi:10.1101/gad.324459.119

\section{Related Content Adaptation to DNA damage checkpoint in senescent telomerase-negative cells promotes genome instability \\ Hélö̈se Coutelier, Zhou Xu, Mony Chenda Morisse, et al. \\ Genes Dev. December , 2018 32: 1499-1513}

\section{License}

Email Alerting Receive free email alerts when new articles cite this article - sign up in the box at the top Service right corner of the article or click here.

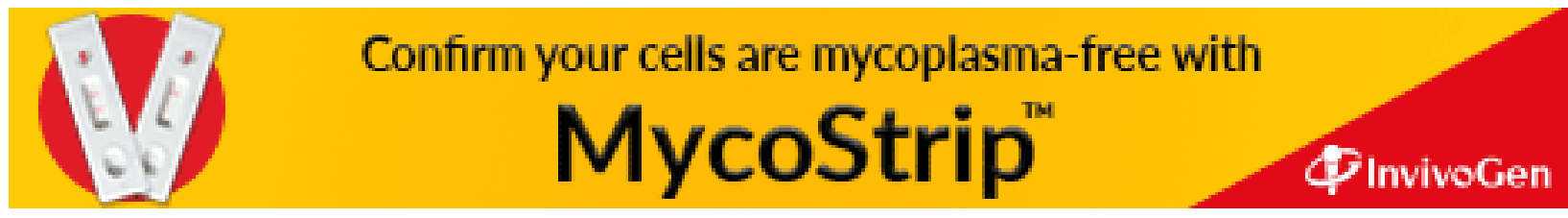

